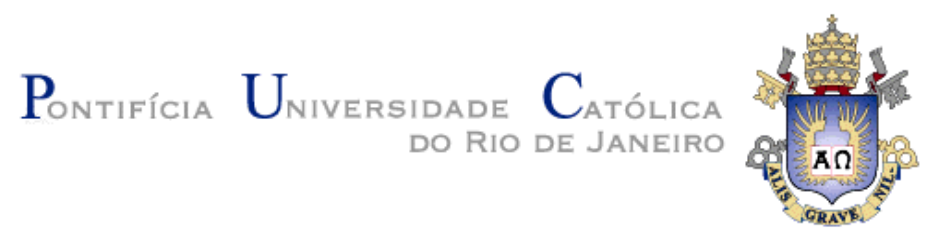

Luiz André Portes Paes Leme

Conceptual schema matching based on similarity heuristics

D.Sc. Thesis

Thesis presented to the Graduate Program of the Departamento de Informática, PUC-Rio in partial fulfillment of the requirements for the degree of Doctor of Science in the subject of Informatics.

Advisor: Prof. Marco Antonio Casanova 


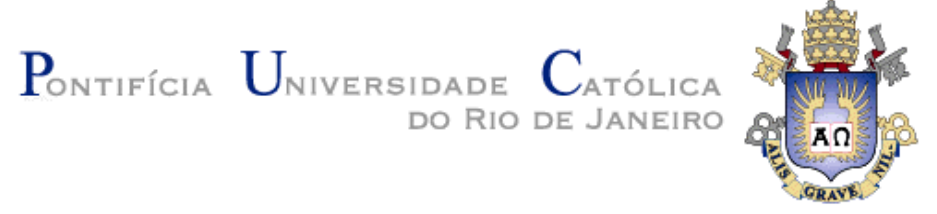

Luiz André Portes Paes Leme

\section{Conceptual schema matching based on similarity \\ heuristics}

Thesis presented to the Graduate Program of the Departamento de Informática, PUC-Rio in partial fulfillment of the requirements for the degree of Doctor of Science in the subject of Informatics.

Prof. Marco Antonio Casanova

Advisor

Departamento de Informática - PUC-Rio

Prof. Antonio L. Furtado

Departamento de Informática - PUC-Rio

Prof. Ruy Luiz Milidiú

Departamento de Informática - PUC-Rio

Prof ${ }^{a}$. Karin Koogan Breitman

Departamento de Informática - PUC-Rio

Prof ${ }^{a}$. Cláudia Bauzer Medeiros Instituto de Computação - UNICAMP

Prof. Angelo Ernani Maia Ciarlini Departamento de Informática Aplicada - UNIRIO

Prof. José Eugenio Leal Coordenador Setorial de Pós-Graduação do CTC - PUC-Rio

Rio de Janeiro - March 23, 2009 
All rights reserved.

\section{Luiz André Portes Paes Leme}

graduated in Electrical Engineering at the Universidade do Estado do Rio de Janeiro (1989), has a Specialization Degree in Distributed Systems from the Núcleo de Computação Eletrônica da UFRJ (2001), and received his Master Degree in Informatics at the Pontifical Catholic University of Rio de Janeiro (2006). He has been acting in software engineering and database design since 1989 for consulting and health plan companies.

Ficha Catalográfica

Leme, Luiz André Portes Paes

Conceptual schema matching based on similarity heuristics / Luiz André Portes Paes Leme ; orientador: Marco Antonio Casanova. - 2009.

106 f. : il. ; $30 \mathrm{~cm}$

Tese (Doutorado em Informática)-Pontifícia Universidade Católica do Rio de Janeiro, Rio de Janeiro, 2009.

Inclui bibliografia

1. Informática - Teses. 2. Banco de dados. 3. Alinhamento de esquema conceitual. 4. Similaridade. I. Casanova, Marco Antonio. II. Pontifícia Universidade Católica do Rio de Janeiro. Departamento de Informática. III. Título. 
To my wife, because of her love and patience in helping me overcome the difficulties. 


\section{Acknowledgments}

To my advisor Prof. Marco Antonio Casanova for the great stimulus and technical knowledge.

To my colleagues at PUC-Rio for innumerous contributions to this work.

To CNPq and PUC-Rio, for the grants which made possible this work.

To the professors which took part in the examination board for their contributions.

To all professors and employees of Informatics Department of PUC-Rio for their precious technical knowledge and help.

To all my family and friends that have encouraged or helped me in any way. 


\section{Resumo}

Leme, Luiz André Portes Paes; Casanova, Marco Antonio. Alinhamento de esquemas conceituais baseado em heurísticas de similaridade. Rio de Janeiro, 2009. 106p. Tese de Doutorado - Departamento de Informática, Pontifícia Universidade Católica do Rio de Janeiro.

Alinhamento de esquema é uma questão fundamental em aplicações de banco de dados, tais como mediação de consultas, integração de banco de dados e armazéns de dados. Nesta tese, abordamos inicialmente o alinhamento de catálogos. Um catálogo é um banco de dados simples que contém informações sobre conjuntos de objetos, tipicamente classificados usando-se termos de um dado tesauro. Inicialmente apresentamos uma técnica de alinhamento baseada na noção de similaridade, que se aplica a pares de tesauros e de listas de propriedades. Descrevemos, então, o alinhamento baseado na noção de informação mútua e introduzimos variações que exploram certas heurísticas. Ao final, discutimos resultados experimentais que avaliam a precisão do método e que comparam a influência das heurísticas. Após as técnicas para alinhamento de catálogos, nos concentramos no problema mais complexo de alinhamento de dois esquemas descritos em um subconjunto de OWL. Adotamos uma técnica baseada em instâncias e, por isso, assumimos que conjuntos de instâncias de cada esquema estão disponíveis. Decompomos este problema nos subproblemas de alinhamento de vocabulário e de alinhamento de conceitos. Introduzimos também condições suficientes para garantir que o alinhamento de vocabulário induz um alinhamento de conceitos correto. Em seguida, descrevemos uma técnica de alinhamento de esquemas OWL baseada no conceito de similaridade. Finalmente, avaliamos a precisão da técnica usando dados disponíveis na Web. De forma diferente de outras técnicas anteriores baseadas em instâncias, o processo de alinhamento que descrevemos usa funções de similaridade para induzir alinhamento de vocabulários de uma forma não trivial. Ilustramos, também, que a estrutura de esquemas OWL pode nos levar a mapeamentos de conceitos errados e indicamos como evitar tais problemas.

\section{Palavras-chave}

Banco de dados. Alinhamento de esquemas conceituais. Similaridade. 


\section{Abstract}

Leme, Luiz André Portes Paes; Casanova, Marco Antonio. Conceptual schema matching based on similarity heuristics. Rio de Janeiro, 2009. 106p. DSc Thesis - Department of Informatics - Pontifical Catholic University of Rio de Janeiro.

Schema matching is a fundamental issue in many database applications, such as query mediation, database integration, catalog matching and data warehousing. In this thesis, we first address how to match catalogue schemas. A catalogue is a simple database that holds information about a set of objects, typically classified using terms taken from a given thesaurus. We introduce a matching approach, based on the notion of similarity, which applies to pairs of thesauri and to pairs of lists of properties. We then describe matchings based on cooccurrence of information and introduce variations that explore certain heuristics. Lastly, we discuss experimental results that evaluate the precision of the matchings introduced and that measure the influence of the heuristics. We then focus on the more complex problem of matching two schemas that belong to an expressive OWL dialect. We adopt an instance-based approach and, therefore, assume that a set of instances from each schema is available. We first decompose the problem of OWL schema matching into the problem of vocabulary matching and the problem of concept mapping. We also introduce sufficient conditions guaranteeing that a vocabulary matching induces a correct concept mapping. Next, we describe an OWL schema matching technique based on the notion of similarity. Lastly, we evaluate the precision of the technique using data available on the Web. Unlike any of the previous instance-based techniques, the matching process we describe uses similarity functions to induce vocabulary matchings in a non-trivial way, coping with an expressive OWL dialect. We also illustrate, through a set of examples, that the structure of OWL schemas may lead to incorrect concept mappings and indicate how to avoid such pitfalls.

\section{Keywords}

Database. Conceptual schema matching. Similarity. 


\section{Contents}

1 Introduction 16

1.1. Motivation and problem definition 16

$\begin{array}{ll}\text { 1.2. Related work } & 18\end{array}$

1.3. Thesis contributions 21

1.4. Thesis outline 24

2 Background $\quad 25$

2.1. RDF/OWL 25

2.2. Similarity models $\quad 27$

2.3. Summary and contributions $\quad 30$

3 Catalogue matching $\quad 32$

3.1. Catalogues, catalogue queries and catalogue matching 32

3.2. An informal example of catalogue matching 34

$\begin{array}{ll}\text { 3.3. Matching heuristics } & 38\end{array}$

3.4. Formalization of catalogue matching 44

3.5. Experiments 49

3.5.1. Data sources 49

3.5.2. Experiments with gazetteers 49

3.5.3. Experiments with book catalogues 57

$\begin{array}{ll}\text { 3.6. Summary and contributions } & 60\end{array}$

4 Complex schema matching $\quad 62$

4.1. OWL Extralite 62

4.2. Vocabulary matching 65

4.2.1. Formal definition of vocabulary matching 65

4.2.2. Instance-based vocabulary matching 66

4.2.3. Experimental results 71

4.3. Concept mapping $\quad 75$

4.3.1. Informal definition of concept mapping rules 75 
4.3.2. Formal definition of concept mapping rules

4.3.3. Concept mappings induced by vocabulary matchings

4.3.4. Consistent concept mappings

4.4. Summary and contributions

5 Conclusions and directions for future work

6 Bibliography

7 Appendix - Setup and calibration of similarity models 


\section{List of figures}

Figure 1. Sets of values assumed by the properties Class1.property1, Class2.property2, Book.author. $\quad 18$

Figure 2. Fragments of the ADL and GEOnet thesauri. 35

Figure 3. RDF triples of fragments of book catalogues. 38

Figure 4. Observed tokens of the title property in the source and target databases of Figure 5.

Figure 5. RDF triples of fragments of book catalogues. 40

Figure 6. RDF triples of fragments of book catalogues with instance matching.

Figure 7. Induced matchings corresponding to Figure 6, using the observed values/tokens heuristic.

Figure 8. Representation of the properties edition and rating of Figure 6 with instance matching heuristic.

Figure 9. An OWL schema for the Amazon Database. 63

Figure 10. An OWL schema for the eBay Database. 64

Figure 11. Similarity of the instances in Table 20 based on the set of tokens representation, where tokens were extracted from all properties.

Figure 12. Similarity of the instances in Table 20 based on the set of tokens representation, where tokens were extracted from matching properties.

Figure 13. The class instance matching algorithm. 70

Figure 14. The contextualized property matching algorithm. 71

Figure 15. Simple SPARQL queries over the Amazon database with $\begin{array}{ll}\text { schema in Figure } 9 & 76\end{array}$

Figure 16. Simple SPARQL query for returning a RDF graph 76

Figure 17. Equivalent queries over the eBay and the Amazon schemas that return titles.

Figure 18. Equivalent queries over eBay and Amazon databases that return titles when only instances of titles of books and music are 
equivalent

Figure 19. Equivalent queries over eBay and Amazon databases that return titles when only instances of titles of books and music are equivalent 


\section{List of tables}

Table 1. Results of querying countries and cities in ADL and GNS. $\quad 36$

Table 2. A fragment of the co-occurrence matrix for ADL and GNS. 51

Table 3. EMI matrix corresponding to the matrix in Table 2.

Table 4. Matchings directly derived from the EMI matrix of Table $2 . \quad 53$

Table 5. ADL property list. 53

Table 6. Reference property matchings for ADL and GNS. 54

Table 7. GNS property list. $\quad 54$

Table 8. Performance of the property matching models directly derived from the EMI matrix. 55

Table 9. A fragment of the co-occurrence matrix for properties of ADL and GEOnet. 56

Table 10. EMI matrix corresponding to the co-occurrence matrix in Table 9.

Table 11. Property matchings corresponding to the third model in Table 10.

Table 12. Amazon property list. $\quad 57$

Table 13. Barnes \& Noble property list. 57

Table 14. Reference property matchings for the Amazon and Barnes \& Noble book catalogues. 58

Table 15. Performance results for the property matching models directly derived from the EMI matrix.

Table 16. A fragment of the co-occurrence matrix for properties of Amazon and Barnes \& Noble corresponding to the first model of Table 15.

Table 17. EMI matrix corresponding to the co-occurrence matrix in Table 17.

Table 18. Property matchings corresponding to the first model in Table 15.

Table 19: Fragment of a vocabulary matching between Amazon and eBay schemas. 
Table 20. Example the same book instance representation in eBay and Amazon.

Table 21. Automatically obtained vocabulary matching from eBay into Amazon

Table 22. Automatically obtained vocabulary matching from eBay into Amazon 


\section{List of Symbols}

$S$ - source schema

$s \quad-\quad$ element of the schema $S$

$T \quad$ - target schema

$t \quad-\quad$ element of schema $T$

$R \quad-\quad$ set of RDF triples that defines the properties and classes of a database schema

$O_{R} \quad-\quad$ subset of an extension R, usually a sample of the database defined by $R$

$O_{R}[P]-\quad$ values of the property $P$ in $o_{R}$

$O_{R}[C]-\quad$ instance ids (URIrefs) of the Class $C$ of $\mathrm{R}$ in $o_{R}$

$R\left[A_{1}, A_{2}, \ldots, A_{n}\right]$ - relation $R$ with properties (attributes) $A_{1}, A_{2}, A_{n}$

$\sigma_{R} \quad-\quad$ set of tuples of $R\left[A_{1}, A_{2}, \ldots, A_{n}\right]$

$\sigma_{R}\left[A_{i}\right]-$ set of values of the property $A_{i}$ in $\sigma_{R}$

$C\left[A_{1} U_{1}, \ldots, A_{m} U_{m}\right]$ - catalogue schema $C$ where $A_{1}$ is the property which holds the id's of the catalogue entries, $A_{2}$ is the classification of the entries, $A_{3}, \ldots, A_{n}$ are the properties of the entries and $U_{1}, \ldots, U_{n}$ are the ranges of each property.

$U_{C}-$ set of RDF triples that defines instances of $C$, a sample of the database

I, J - instances of catalogues

$\mu_{P}-$ property matching between two catalogue schemas

$\mu_{T} \quad-\quad$ thesauri terms matching between two catalogue schemas

$\mu_{l} \quad-\quad$ instance matching between two schemas

$o\left[C, A_{i}\right]$ - values of the property $A_{i}$ in $U_{C}$

ot $\left[C, A_{i}\right]$ - tokens of a string property $A_{i}$ in $U_{C}$

$i v\left[C, A_{i}\right]$ - (instance id,value) ordered pairs of the property $A_{i}$ in $U_{C}$

$i[C, t]$ - set of instance id's classified as $t$ in a thesaurus $T$

$V_{S}-$ set of properties and classes of the database schema $S$

$C_{S}-$ set of classes in $V_{S}$

$P_{S} \quad-\quad$ set of properties in $V_{S}$ 
$\mu_{V} \quad$ - vocabulary matching between two database schemas

$\mu_{C} \quad-\quad$ class matching between two database schemas

props $[S, C]$ - properties of the class $C$ in the database schema $S$

relprops $[S, C, T, D]$ - properties of class $C$ in the database schema $S$ where the matching properties with the class $D$ of schema $T$ is replaced by the equivalent property of $D$.

$P^{C} \quad-\quad$ contextualized property $P$ : a property $P$ attached to instances of the class $C$

tp - amount of true positive matchings. A true positive matching is that matching either pointed out by the matching algorithm and that it comes to be valid given a matching reference.

fp - amount of false positive matchings. A false positive matching is that matching pointed out by the matching algorithm, but that it is not valid given a matching reference.

tn - the amount of true negatives matchings. A false negative matching is that matching either missed by the matching algorithm and that it is not valid given a matching reference.

fn - the amount of false negatives matchings. A false negative matching is that matching missed by the matching algorithm, but it comes to be true given a matching reference. 